\title{
Effect of Synergy on Financial Performance of Merged Financial Institutions in Kenya
}

\author{
Agnes Ogada ${ }^{1}$, Amos Njuguna ${ }^{1} \&$ George Achoki ${ }^{1}$ \\ ${ }^{1}$ Chandaria School of Business, United States International University, Kenya \\ Correspondence: Agnes Ogada, Chandaria School of Business, United States International University, P O Box \\ 35596, 00200 Nairobi, Kenya. Tel: 722-520-301. E-mail: owuorogada@ gmail.com
}

Received: June 27, 2016

Accepted: July 21, 2016

Online Published: August 25, 2016

doi:10.5539/ijef.v8n9p199

URL: http://dx.doi.org/10.5539/ijef.v8n9p199

\begin{abstract}
Mergers and Acquisitions deals that create value constitute at least one or a combination of financial and operational synergy. This paper investigates the effect of synergy on financial performance of merged institutions in the financial services sector in Kenya. The paper adopted a mixed research design, pre and post-merger secondary data was collected from 40 (forty) institutions in the Kenyan financial services industry that had concluded their merger processes by 31 December 2013. Financial synergy was proxied using the liquidity ratio while operating synergy was measured using growth in sales. Primary data was used to explain the results of the secondary data. Panel data analysis was used to determine the change in the study variables and trends over time between 2009 and 2013, event window (pre-merger and post-merger) analysis was used to test for any significant difference in performance means before and after merger as a result synergy, while regression analysis was used to determine the relationship between synergy and profitability. Results show that there is a positive relationship between performance, operating synergy and financial synergy, and that there was significant improvement in performance post-merger. From these findings, the study recommends that institutions should critically evaluate the overall business and operational compatibility of the merging institutions and focus on capturing long-term financial synergies as this has a positive effect on the performance.
\end{abstract}

Keywords: mergers and acquisitions, ROA, ROE, operating synergy, financial synergy, financial services sector

\section{Introduction}

Mergers \& Acquisitions (M\&A) continue to play a major role in shaping business activities. Once a phenomenon seen primarily in the United States of America, M\&A are now taking place in countries throughout the world. Continental Europe has experienced M\&A bursts coupled with relative inactivity both domestically and across national borders (Hitt, Harrison, \& Ireland, 2001). The first real increase in M\&A activity in the UK, on the other hand, can be traced back to the 1920's when the development of mass production techniques created an increase in the vertical integration through scale of production, while the second M \&As wave came in the 1960s as a response to the internationalization of the world economy. There was need for M\&A to create larger firms that would be effective in international competition especially from countries like the US and Japan (Sudarsanam, 2003).

In Africa, M\&A activities have become important channels for investment for both global and local market players as they have allowed companies to consolidate their positions in African markets, contributing to better market access and competitiveness. Nevertheless, the African M\&A market is still very small compared to other regions in the world (DiGeorgio, 2002). There are also regional disparities within the continent as the market is essentially dominated by deals in Northern and Southern Africa (Kim \& Mauborgne, 2005). The attractiveness of the African continent for M\&A deals is mainly underpinned by the high economic growth and the buoyant energy, mining and utilities sectors.

In Kenya Mergers and Acquisitions are regulated by The Restrictive Trade Practices, Monopolies and Price Control Act (Cap 504 Laws of Kenya). According to (Mwaniki, 2015), Mergers and acquisitions (M\&A) slowed down in the first four months of 2015 compared to the same period in 2014 in Kenya. This occurred despite the multi-billion shilling Equity and Centum share deals. The advisory firm Burbidge Capital that compiles data on corporate deals in East Africa shows that 2015 saw 11 M\&A deals compared to 17 in the first four months of 2014. Sector wise, the financial services sector led with $10.4 \%$ of the total deals in 2015 , followed by 
manufacturing (8.3\%), real estate (2.8\%) and oil industry (2.8\%). Kenya has kept its position as the leading M\&A hotspot in East Africa; analysts predict that the insurance sector currently remains the most likely focus area for mergers and acquisitions in 2015 because of its high growth potential and higher capital demands. Banks are also the likely growth area in M\&A in future, as the country is having too many banks (43) which makes it difficult for any single lender to take on financing of large-scale projects due to capital constraint. (Mwaniki, 2015).

M\&A literature and several economic theories support the notion that shareholders experience positive abnormal returns as a result of the anticipated value creation post-merger (Halebian, Cynthia, McNamara, Carpenter, \& Davidson, 2009; Cartwright \& Cooper, 1993; Moeller, Schlingemann, \& Stulz, 2005). Thus, M\&A are expected to create value as a result of firms exploiting economic resources that are both available and implementable leading to synergy. The primary objective for any merger or takeover would be to create value for shareholders that will exceed the cost of the acquisition; as such synergy appears to be a tangible justification for M\&A or takeovers. Once the merger process has taken place, achieving synergies is not always realized since the two companies ultimately operate as one unit to realize such synergies. There ought to be economies of scale as the entities' resources are consolidated to function as one unit (Sudarsanam, 2003; Marks \& Mirvis, 2010). Operating synergy refers to the improvement of production and operational efficiency of enterprises which are caused by economies of scale and economy of scope after M\&A. Financial synergy refers to the financial benefits generated by M\&A transaction; it is a net cash flow on benefits which are caused by tax laws, accounting standards and other provisions of the securities exchange ((Sudarsanam, 2003; Marks \& Marvis, 2010).

\subsection{Problem Statement}

Limited studies have been carried out on the M \& A in the Kenyan market. These studies' findings have not shown that M\&A activities positively affect financial performance. Some of them even give contradictory findings. Chesang (2002) studied implications of merger restructuring on performance of commercial banks in Kenya and using ratio analysis, she concluded that although there was improved performance in some cases, the extent of the contribution was not significant. Korir (2006) studied merger effects of companies listed in the NSE and concluded that mergers improve performance of companies listed at the NSE. Ochieng (2006) showed results that indicated a decline in earnings and lower ratios when Commercial Bank of Africa merged with First American Bank Kenya Limited. Marangu (2007) studied effects of mergers on financial performance of non-listed banks in Kenya from 1994-2001 and results of ratio analysis showed that there was significant improvement in performance for the non-listed banks which merged compared to the non-listed banks that did not merge within the same period. Studies carried out by (Misigah, 2013; Maranga, 2010; Katuu, 2003; Muya, 2006; Kiplagat, 2006; Wesonga, 2006; Nyagah, 2007; Njoroge, 2007; Kithinji, 2007, Ndura, 2010, Ndung'u, 2011, and Ireri, 2011) have not confirmed that mergers and acquisitions are effective strategic activities. This presents a conceptual knowledge gap. The study therefore sought to find out if synergy related M \&A are real strategic activities that lead to improved performance of merged Institutions in the Kenyan financial service Industry.

\section{Literature Review}

Synergistic merger theory suggests that the bidder firm can achieve efficiency gains by combining an efficient target with their businesses thereby improving the target's performance. Bidder firms often recognize specific complementarities between their businesses and that of the target; therefore even though the target is already performing well, it should perform even better when it is combined with its complementary counterpart, the bidder firm. The theory suggests that targets perform well both before and after the merger (Chatterjee, 1986; Altunbas \& Ibanez, 2008; Hankir, Rauch, \& Umber, 2011). The implication of this is that operating synergies are achievable in horizontal, vertical and even conglomerate mergers. The synergy theory makes the assumption that economies of scale exists in the industry and that before the merger, the firms are merely operating at levels of activity that fall short of achieving the economies of scale (Chatterjee, 1986; Weston, Chung, \& Hoag, 2003; Altunbas \& Ibanez, 2008; Hankir et al., 2011).

Operating synergy can be implemented through revenue enhancement or cost reducing measures. Potential sources of revenue enhancements might come from sharing of marketing opportunities by cross-marketing each merger partner's product (Gaughan, 2011). The main source of operating synergy however comes from cost reductions. Cost reductions may be the result of economies of scale; thus the decreases in unit cost that result from an increase in the size or scale of company's operations, elimination of duplicate functions and back office operations. Hellgren, Lowstedt, and Werr (2011) and Hankir et al. (2011) explain the possibilities for increased 
revenues resulting from cross selling, and cost reductions arising from efficiency gains.

The financial synergy theory on the other hand is based on the proposition that nontrivial transaction costs associated with raising capital externally as well as the differential tax treatment of dividends; may constitute a condition for more efficient allocation of capital through mergers from low to high marginal returns, production activities, and possibly offer a rationale for the pursuit of conglomerate mergers (Weston et al., 2003). The theory also states that when the cash flow rate of the acquirer is greater than that of the acquired firm, capital is relocated to the acquired firm and its investment opportunities improve. According to (Gaughan, 2011); financial synergy refers to the impact of a corporate merger or acquisition on the costs of capital to the acquiring firm or the merging partners. The extent to which financial synergy exists in corporate combinations, the costs of capital should be lowered. Another widely discussed proposition is that the debt capacity of the combined firm can be greater than the sum of the two firms' capacities before the merger, and this provides tax savings on investment income (Weston et al., 2003). Mergers contribute to lower cost of capital in that companies substantially increase their sizes as a result of a merger will have more assets hence higher debt capacity. A company with investment opportunities and another with cash slack may combine to achieve financial synergy (Gaughan, 2011).

An empirical study by Misigah (2013) examined the effect of mergers and acquisitions in achieving synergy for commercial banks in Kenya. The population of the study comprised of 15 commercial banks which had successfully completed their merger and acquisition transactions between the years 2000-2010. Comparison and analysis of ratios was used to compare the effect of mergers on growth in assets, profitability and shareholders' value during the pre-merger period and post-merger period. The Wilcoxon Signed Ranks Test was used to determine the significant difference in growth before and after the merger activity. Results indicated that the main reason why the bank undertook merger was growth in shareholders' value and growth in profitability. Results showed that there was significant growth in profitability and synergy as a result of the merger.

Marangu (2007) studied the effects of mergers and acquisition on financial performance of non-listed commercial banks in Kenya. The research focused on the profitability of non-listed banks which merged from 1994 to 2001 and used four measures of performance: profit, return on assets, shareholders equity/total assets, and total liabilities/total assets. Comparative analysis of the bank's performance for the pre and post-merger periods was conducted to establish whether mergers lead to improved financial performance after merging as compared to before. The results of the data analysis showed that three measures of performance: profit, ROA and shareholders' equity/total assets had values above the significance level of 0.05 with exception of total liabilities/total assets. The results concluded that there was significant improvement in performance for the non-listed banks which merged compared to the non-listed banks that did not merge within the same period. This confirms the theoretical assertion that firms derive more synergies by merging than by operating as individual outfits

Amegah (2012) examined the impact of mergers and acquisitions on the acquiring company's corporate financial performance, within the Ghanaian economy, using Vodafone Ghana as case study. The issue was investigated using performance measures based on the company's annual reports and a non-parametric test was carried out on the views of customers and staff in order to know the areas of improvements after the acquisition. Results of the study showed that the accounting performance had increased in some aspects and declined in others after the merger. Sales growth increased during the post-mergers periods since it had the same trend with the pre-mergers period but much higher values in the post-mergers periods. Operating expense and financial leverage had decreased while liquidity was on the rise after the merger.

Junge (2014) evaluated operating performance changes by different synergy types after the merger. The study sample was 420 mergers that took place between 1988 and 2008. Results showed significant improvements of operating performance during post-merger period. The mergers that strived for efficiency synergy exhibited stronger performance improvements; while those that strived for synergy from complementary resources or market power, showed low level of performance improvement. The performance improvements were majorly from the increase in cash flow margins and lower investments in the post-merger period. There was positive relationship of the revaluation of the firm's assets around the merger announcement and the change in operating performance. This is the relationship that establishes the link of post-merger performance improvements towards shareholder value creation. It is therefore concluded that post-merger performance improvements confirm the existence of merger-induced synergy. These synergistic gains are found to be especially large for efficiency synergies, while synergy from complementary resources is substantially lower and almost no evidence could be found for the existence of market power synergy. 


\section{Research Methodology}

A mixed research design was adopted for the study. Quantitative data from the audited financial statements of the financial institutions was used to determine the operating synergy (growth in sales) and financial synergy (liquidity ratio), return on assets and return on equity ratios of the sampled firms before and after the merger; while qualitative data was used to explain the results. The population of the study consisted of 51 firms drawn from both the insurance and banking industries in Kenya by 31 December 2013. Eleven institutions were omitted from the sample as a result of missing data; hence conclusions and inferences were based on 40 (forty) firms. Primary data was collected using a self-constructed questionnaire administered on random basis to 120 managers in the merged firms (response rate was $69 \% ; n=83$ was) was achieved. Panel data was generated by pooling time-series observations across merged financial institutions between 2009 and 2013. Event window methodology which consisted of pre and post analysis was also used to gauge the mean performance before and after the merger as a result of synergy. The regression analysis model was used to test the relationship between the dependent and independent variables.

\section{Findings}

\subsection{Financial Data}

Table 1. Financial synergy

\begin{tabular}{ccccccc}
\hline Variable & Year & Observations & Mean & Std. Dev. & Min & Max \\
\hline Financial Synergy & 2009 & 40 & 0.36131 & 0.11331 & 0.15889 & 0.71444 \\
& 2010 & 41 & 0.35836 & 0.10791 & 0.16667 & 0.69333 \\
& 2011 & 41 & 0.33957 & 0.10628 & 0.16 & 0.63 \\
& 2012 & 42 & 0.37716 & 0.12362 & 0.15 & 0.82 \\
Average & 2013 & 42 & 0.37258 & 0.11081 & 0.19 & 0.6423 \\
\hline
\end{tabular}

Results in Table 1 above indicate the descriptive statistics of financial synergy from the secondary data collected. As indicated in the table, the mean financial synergy was $36 \%$ with the minimum and maximum ranging between $33 \%$ and $37 \%$. The standard deviation on the other hand was averaged $11 \%$ indicating insignificant variability in financial synergy over time.

Table 2. Operating synergy

\begin{tabular}{ccccccc}
\hline Variable & \multicolumn{1}{c}{ Year } & Observations & \multicolumn{1}{c}{ Mean } & \multicolumn{1}{l}{ Std. Dev. } & \multicolumn{2}{c}{ Min } \\
\hline Operating Synergy & 2009 & 6 & 0.0767 & 0.1093 & -0.19 & 0.09 \\
& 2010 & 36 & 0.0608 & 0.11085 & -0.19 & 0.36 \\
& 2011 & 41 & -0.03202 & 0.28061 & -0.2 & 1.27 \\
& 2012 & 40 & -0.01255 & 0.16247 & -0.2 & 0.64 \\
Average & 2013 & 39 & 0.0366 & 0.11584 & -0.2 & 0.33 \\
\hline
\end{tabular}

Results in Table 2 above indicate the descriptive statistics of operating synergy from the secondary data collected. The mean operating synergy was 3\% with the minimum and maximum for the period 2009 to 2013 ranging between $-3 \%$ and $7 \%$ indicating an insignificant increase in operating synergy over time, The standard deviation mean was $15 \%$ indicating significant variability in operating synergy over time.

Table 3. Financial synergy pre and post-merger analysis

\begin{tabular}{lccccccc}
\hline & Merger period & N & Mean & Std. Deviation & Std. Error Mean & t & Sig. (2-tailed) \\
\hline Financial Synergy & 1 & 23 & 41.913 & 10.50936 & 2.19135 & 5.197 & 0 \\
& 0 & 45 & 29.3556 & 8.26591 & 1.23221 & & \\
\hline
\end{tabular}

To test whether there is a statistical difference in financial synergy mean before and after merger, an event window analysis was carried out. Results in Table 3 above indicate that, there is a significant statistical 
difference in financial synergy means before and after merging. This implies that merging improved the liquidity of the merged institutions.

Table 4. Operating synergy pre and post-merger analysis

\begin{tabular}{cccccccc}
\hline & Merger period & N & Mean & Std. Deviation & Std. Error Mean & t & Sig. (2-tailed) \\
\hline Operating synergy & 1 & 23 & 0.79087 & 0.10063 & 0.020983 & 15.242 & 0.000 \\
& 0 & 45 & 0.428222 & 0.084619 & 0.012614 & & \\
\hline
\end{tabular}

To test whether there is a statistical difference in operating synergy mean before and after merger, an event window analysis was carried out. Results in Table 4 above indicates that, there is a significant statistical difference in operating synergy means before and after merging. This implies that merging improved the sales of the merged institutions.

Table 5. Return on Asset (ROA)

\begin{tabular}{ccccccc}
\hline Variable & Year & Observations & Mean & Std. Dev. & Min & Max \\
\hline ROA & 2009 & 41 & 0.185122 & 1.021311 & -0.16 & 6.56 \\
& 2010 & 42 & 0.195714 & 1.038085 & -0.1 & 6.76 \\
& 2011 & 42 & 0.351667 & 1.973464 & -0.22 & 12.83 \\
& 2012 & 43 & 0.16 & 0.779741 & -0.15 & 5.14 \\
& 2013 & 43 & 0.030698 & 0.045846 & -0.16 & 0.09 \\
\hline \multicolumn{2}{r}{} & & $\mathbf{0 . 1 8 4 6 4}$ & $\mathbf{0 . 9 7 1 6 9}$ & & \\
\hline
\end{tabular}

Results in Table 5 above indicate the descriptive statistics of ROA from the secondary data. As indicated the mean ROA for the period was $18 \%$ with the minimum and maximum for the period ranging from $3 \%$ and $35 \%$. The standard deviation of $.97 \%$ indicates a significant variability in ROA over time.

Table 6. Return on Equity (ROE)

\begin{tabular}{ccccccc}
\hline Variable & Year & Observations & Mean & Std. Dev. & Min & Max \\
\hline ROE & 2009 & 41 & 0.14317 & 0.0526 & 0.05 & 0.31 \\
& 2010 & 42 & 0.11524 & 0.04748 & 0.05 & 0.26 \\
& 2011 & 42 & 0.16833 & 0.10613 & 0.05 & 0.46 \\
& 2012 & 43 & 0.1693 & 0.09767 & 0.05 & 0.47 \\
& 2013 & 43 & 0.12372 & 0.03786 & 0.06 & 0.19 \\
\hline & Average & $\mathbf{0 . 1 4 3 9 5}$ & $\mathbf{0 . 0 6 8 3 5}$ & & \\
\hline
\end{tabular}

Results in Table 6 above indicates the descriptive statistics of ROE from the secondary data. As indicated, mean ROE for the period 2009 to 2013 was $14 \%$ with a mean standard deviation of $6 \%$ indicating insignificant variability in ROE over time. The mean ROE for the period 2009 to 2013 ranged between $11 \%$ and $17 \%$.

\subsection{Effect of Synergy on Financial Performance}

Table 7. Correlation analysis for synergy and financial performance

\begin{tabular}{llcccc}
\hline \multirow{2}{*}{ ROA } & & ROA & ROE & Financial synergy & Operating synergy \\
& Pearson Correlation & 1 & $.410^{* *}$ & $.150^{*}$ & $.352^{* *}$ \\
ROE & Sig. (2-tailed) & & 0.000 & 0.031 & 0.000 \\
& Pearson Correlation & $.410^{* *}$ & 1 & 0.019 & $.209^{* *}$ \\
Financial synergy & Sig. (2-tailed) & 0.000 & & 0.791 & 0.008 \\
& Pearson Correlation & $.150^{*}$ & 0.019 & 1 & -0.045 \\
Operating synergy & Sig. (2-tailed) & 0.031 & 0.791 & & 0.573 \\
& Pearson Correlation & $.352^{* *}$ & $.209^{* *}$ & -0.045 & 1 \\
\hline
\end{tabular}

** Correlation is significant at the 0.01 level (2- tailed);

* Correlation is significant at the 0.05 level (2-tailed). 
Table 7 above presents the results of the correlation analysis between financial synergy, operation synergy, ROA and ROE. The results show that there is a positive relationship between ROA, operating synergy and financial synergy $(\mathrm{r}=.352, \mathrm{p}=0.000),(\mathrm{r}=.150, \mathrm{p}=0.031)$.

Table 8. Regression analysis operating synergy

\begin{tabular}{lll}
\hline & ROA & ROE \\
\hline Parameter estimate & Coefficient(P value $)$ & Coefficient(P value) \\
\hline Constant & $.226(0.12)$ & $.147(0.000)$ \\
Operation Synergy & $2.299(0.000)$ & $0.95(0.08)$ \\
R Squared & 0.124 & 0.44 \\
F statistic (ANOVA) & $28.616(0.000)$ & $0.48(0.08)$ \\
\hline
\end{tabular}

Regression results indicate the goodness of fit for the regression between operating synergy and ROA. R squared of 0.124 indicates that $12.4 \%$ of the variations in ROA are explained by operating synergy. The overall model of operation synergy and ROA is significant with an F statistic of 28.616.

The regression equation is therefore:

$\mathrm{ROA}=0.226+2.299$ Operating Synergy

ROE $=0.147+0.95$ Operating Synergy

This implies that an increase in Operating synergy leads to a 2.299 increase in ROA while an increase in Operating synergy leads to a 0.95 increase in ROE.

Table 9. Regression analysis financial synergy

\begin{tabular}{lll}
\hline & ROA & ROE \\
\hline Parameter estimate & Coefficient(P value) & Coefficient(P value) \\
\hline Constant & $-.371(0.170)$ & $0.139(0.00)$ \\
Financial Synergy & $1.545(0.31)$ & $0.13(0.791)$ \\
R Squared & 0.23 & 0.000 \\
F statistic (ANOVA) & $6.171(0.31)$ & $0.00(0.791)$ \\
\hline
\end{tabular}

Regression analysis was conducted to empirically determine whether financial synergy was a significant determinant of performance which is measured in ROA and ROE. Regression results in indicated the goodness of fit for the regression between financial synergy and ROA. R squared of 0.23 indicates that $23 \%$ of the variations in ROA are explained by financial synergy. The overall model of financial synergy and ROA as shown in table 9 above was non-significant.

Based on the regression analysis it can be seen that there is is a relationship between synergy and financial performance of merged institutions.

\section{Discussion of Results}

The study results from secondary show the mean financial synergy of $36 \%$, while primary data results show that $71 \%$ of the respondents indicated that M\&A led to shared sources of long term finance and $61 \%$ of respondents agreed that M\&A led to shared sources of overdraft facility. Results of operating synergy from the secondary data showed a mean of $3 \%$ while primary data results show that $66 \%$ of respondents indicated that $\mathrm{M} \& \mathrm{~A}$ led to shared markets, $63 \%$ agreed that $M \& A$ led to shared human resource talents while $65 \%$ agreed that $M \& A$ led to shared marketing efforts

Overall results show that there is a positive relationship between ROA, ROE, operation synergy and financial synergy; and that there is statistical difference in synergy means before and after the merger. The findings agree with those of Misigah (2013) who examined the effect of mergers and acquisitions in achieving synergy for commercial banks in Kenya. The population of the study comprised of 15 commercial banks which had successfully completed merger and acquisition transactions between the years 2000-2010. Results showed that there was significant growth in profitability and synergy as a result of the merger.

The study findings also agree with that of Marangu (2007) who studied the effects of mergers and acquisitions 
on financial performance of non-listed commercial banks in Kenya. The research focused on the profitability of non - listed banks which merged from 1994 to 2001 and used four measures of performance: profit, return on assets, shareholders equity/total assets, and total liabilities/total assets. The results of the data analysis showed that three measures of performance: profit, ROA and shareholders' equity/total assets had values above the significance level of 0.05 with exception of total liabilities/total assets. The results concluded that there was significant improvement in performance for the non-listed banks which merged compared to the non-listed banks that did not merge within the same period. This confirms the theoretical assertion that firms derive more synergies by merging than by operating as individual outfits.

The study also agrees with that of Amegah (2012) who examined the impact of mergers and acquisitions on the acquiring company's corporate financial performance, within the Ghanaian economy, using Vodafone Ghana as case study. The issue was investigated using performance measures based on the company's annual reports and a non-parametric test was carried out on the views of customers and staff in order to know the areas of improvements after the acquisition. Results of the study showed that sales growth increased during the post-merger periods since it had the same trend with the pre-merger period but much higher values in the post-mergers periods. Operating expense and financial leverage had decreased while liquidity was on the rise after the merger.

\section{Conclusions}

The study sought to establish the effect of synergy on financial performance and found that there is positive relationship between operating synergy, financial synergy and financial performance of merged institutions. The implication is that synergy improves performance in terms of profitability and that merger activity led to the following; shared marketing efforts, shared human resource talents, shared source of long term finance and improved liquidity arising from the cash and cash equivalents of the merged firms and shared working capital.

\section{Recommendations}

From the study findings, synergy was found to have a positive effect on financial performance. It is therefore recommended that institutions should critically evaluate the overall business and operational compatibility of the merging institutions and focus on capturing long-term financial synergies. They should increase their scope to create high performing supply chains with significant long-term upside that provide sustained value for customers and stakeholders.

\section{Limitations of the Study and Suggestions for Further Research}

The main limitation of the study was that only forty (40.) merged Institutions whose audited financial statements were available were investigated. The study was limited in scope as it only investigated effect of synergy on performance of merged institutions even though there are many other factors such as cost efficiency that may affect performance as the result of the merger. Additionally, the regression results based on the panel data was only for 5 years (2009-2013).

Further studies should be carried out by incorporating more variables both the quantitative and qualitative should be included in the studies to come up with a more comprehensive conclusion. Researchers and academicians should carry out other studies on the effect of mergers and acquisitions strategies on financial performance of different sectors such as manufacturing and processing industries to help in drawing a parallel with the effects in the financial services sector.

\section{References}

Altunbaş, Y., \& Ibanez, D. M. (2008). Mergers and acquisitions and bank performance in Europe: The role of strategic similarities. Journal of Economics and Business, 60(3), 179-290. http://dx.doi.org/10.1016/j.jeconbus.2007.02.003

Amegah, W. (2012). Mergers and Acquisition: Vodafone Gt Case. Unpublished Master's Thesis, Kwame Nkrumah University of Science and Technology

Cartwright, S., \& Cooper, C. L. (1993). The role of culture compatibility in successful organizational marriage. The Academy of Management Executive, 7(2), 57-70. http://dx.doi.org/10.5465/ame.1993.9411302324

Chatterjee, S. (1986). Types of synergy and economic value: The impact of acquisitions on merging and rival firms. Strategic Management Journal, 7(2), 119-139. http://dx.doi.org/10.1002/smj.4250070203

Chesang, C. J. (2002) Merger Restructuring and Financial Performance of Commercial Banks in Kenya. Unpublished Dissertation, School of Business, University of Nairobi. 
Cornett, M. M., McNutt, J. J., \& Tehranian, H. (2006). Performance changes around bank mergers: Revenue enhancements versus cost reductions. Journal of Money, Credit and Banking, 38(4), 1013-1050. http://dx.doi.org/10.1353/mcb.2006.0053

DiGeorgio, R. M. (2002). Making mergers and acquisitions work: What we know and don't know Journal of Change Management, 3(3), 259-274. http://dx.doi.org/10.1080/714042539

Gaughan, P. A. (2011). Mergers, Acquisitions and Corporate Restructurings (5th ed.). New Jersey, NJ: John Wiley \& Sons.

Halebian, J., Cynthia, E., McNamara, G., Carpenter, M., \& Davidson, R. (2009). Taking stock of what we know about mergers and acquisitions: A review and research agenda. Journal of Management, 35(3), 469-502. http://dx.doi.org/10.1177/0149206308330554

Hankir, Y., Rauch, C., \& Umber, M. P. (2011). Bank M\&A: A market power story? Journal of Banking \& Finance, 35(9), 2341-2354. http://dx.doi.org 10.1016/j.jbankfin.2011.01.030

Hellgren, B., Löwstedt, J., \& Werr, A. (2011). The reproduction of efficiency theory: The construction of the Astrazeneca merger in the public discourse. International Journal of Business and Management, 6(5), 16-27. http://dx.doi.org/10.5539/ijbm.v6n5p16

Hitt, M. A., Harrison, J. S., \& Ireland, R. D. (2001). Mergers and Acquisitions: A Guide to Creating Value for Stakeholders. Oxford: Oxford University Press.

Ireri, J. K. (2011). Effects of mergers and acquisitions on financial performance of oil companies in Kenya. Unpublished Dissertation, School of Business, University of Nairobi.

Junge, L. M. (2014). Operating Synergy; Types and their Impact on post-merger Performance. Master Thesis, Department of Finance, Faculty of Economics and Business Administration. Tilburg University.

Katuu, J. M. (2003). A survey of Factors Considered Important in Merger \& Acquisition Decisions by Selected Kenyan Based Firms. Unpublished Dissertation, School of Business, University of Nairobi.

Kim, W. C., \& Mauborgne, R. (2005). Blue Ocean Strategy. Harvard Business School Press.

Kiplagat, E. (2006). Effects of Mergers on Financial Performance of Companies Listed at the NSE. Unpublished Dissertation, School of Business, University of Nairobi.

Kithinji, M. (2007). Effects of Mergers on Financial Performance of Non Listed Banks in Kenya. Unpublished Dissertation, School of Business, University of Nairobi.

Korir, P. (2006). Merger effects of companies listed in the NSE. An unpublished MBA project, University of Nairobi.

Lewellen, W. G. (1970) A pure financial rationale for the conglomerate merger. Journal of Finance, 27(8), 521-537.

Maranga, C. (2010). Effects of mergers and acquisitions on cost and scale efficiency of the combined commercial banks in Kenya. Unpublished Dissertation, School of Business, University of Nairobi.

Marangu, K. (2007). Effects of mergers on financial performance of non-listed banks in Kenya (Doctoral dissertation, University of Nairobi.). Nairobi, KE: University of Nairobi

Marks, M. L., \& Mirvis, P. H. (2010). Joining Forces: Making One Plus One Equal Three in Mergers, Acquisitions and Alliances (2nd ed.). Jossey Bass Publishers

Misigah, G. (2013). Effects of mergers and acquisition on growth: A study of Commercial Banks in Kenya. Master's Thesis. Unpublished Thesis.

Moeller, S. B., Schlingemann, F. P., \& Stulz, R. M. (2005). Wealth destruction on a massive scale? A study of acquiring-firm returns in the recent merger wave. The Journal of Finance, 60(2), 757-782. http://dx.doi.org/10.1111/j.1540-6261.2005.00745.x

Muya, C. M. (2006). A Survey of Experiences of Mergers. Unpublished Dissertation, School of Business, University of Nairobi.

Mwaniki, C. (2015). Kenya's merger, acquisition deals slowdown in 2015. Business Daily June, 2015.

Ndung'u, B. M. (2011). Effects of mergers and acquisitions on the financial performance of commercial banks in Kenya. Unpublished Dissertation, School of Business, University of Nairobi

Ndura, K. M. (2010). Effects of mergers on financial performance of insurance companies in Kenya. 
Unpublished Dissertation, School of Business, University of Nairobi.

Njoroge, F. W. (2007). A Survey of Mergers \& Acquisitions Experiences by Commercial Banks in Kenya. Unpublished Dissertation, School of Business, University of Nairobi.

Nyagah, B. W. (2007). Doctor's perception of mergers \& acquisitions in the pharmaceutical industry in Kenya. Unpublished Dissertation, School of Business, University of Nairobi

Ochieng, A. (2006). Bank consolidations and competition the issue of Kenya's many small banks. Marketing Intelligence Banking Industry Survey, 18-24.

Sudarsanam, S. (2003). Creating Value from Mergers and Acquisitions - The Challenges, Prentice Hall, Inc.

Wesonga, M. (2006). A Survey of the Factors that Determine the Choice of Mergers \& Acquisition Partners in Kenya. Unpublished Dissertation, School of Business, University of Nairobi.

Weston, J. F., Chung, K. S., \& Hoag, S. E. (2003). Mergers, Restructuring, and Corporate Control. Englewood Cliffs, New Jersey: Prentice Hall, Inc.

\section{Copyrights}

Copyright for this article is retained by the author(s), with first publication rights granted to the journal.

This is an open-access article distributed under the terms and conditions of the Creative Commons Attribution license (http://creativecommons.org/licenses/by/4.0/). 